\title{
Birinci Dünya Savaşında Suriye'de Panislamist Propaganda: Eş-Şark Gazetesi Örneği
}

\author{
M. Talha ÇiçEK*
}

Öz

Bu makale Birinci Dünya Savaşı esnasında, Suriye'de Cemal Paşa'nın kararıyla Arapça olarak yayımlanan ve İttihad-1 İslam propagandası yapmayı amaçlayan eş-Şark gazetesi hakkındadır. Makale gazetenin kuruluş amacı ve söylemini analiz etmekte, etkisine dair bazı çıkarımlarda bulunmaktadır. Panislamizm savaş döneminde Osmanlı Devleti’nin bir tür resmi ideolojisi niteliğindeydi. Osmanlı tabiiyetinde bulunan veya bulunmayan Müslümanların, İmparatorluğun savaş hedeflerini desteklemesinin sağlanması da bu ideolojinin temel motivasyonlarından biriydi. Eş-Şark ve benzeri araçlar vasıtasıyla dünya Müslümanları kolonyal Avrupa devletlerin amaçları hakkında aydınlatılacak ve böylece Müslüman sömürgeler arasında anti-kolonyal isyanlar patlak verecekti. Bu doğrultuda, Hilafet, Osman11 Devleti'nin devam etmesinin önemi ve Şerif Hüseyin ve Mısır Sultanı gibi "isyancıların" "ihaneti" dergide yayınlanan makalelerde en çok işlenen temalar arasındaydı. Muhammed Kürd Ali ve Şekib Arslan gibi Suriye'nin önde gelen ilim ve fikir adamları da gazeteye yazılarıyla katkıda bulunmuşlar ve gazetede idari görevler üstlenmişlerdir. Makale, eş-Şark gazetesinin nüshalarından faydalanmanın yanında, Osmanlı, İngiliz, Alman ve Avusturya arşivlerindeki konuyla ilgili belgeleri de içermektedir. Bu makalede Mary Mills Patrick'in kısa hayat hikayesiyle beraber Türk eğitim sistemine ve onun özellikle kızların eğitimine yaptı̆̆ önemli katkılara işaret edilecek. Ayrıca yukarda adı geçen eseri çerçevesinde Türk kızlarının eğitim hayatına dahil olmalarında oynadığı rol üzerinde durulacaktır. Bu katıkıları işaret edilmimiş

Anahtar Kelimeler: Cemal Paşa, Eş-Şark, I. Dünya Savaşı, Panislamizm, Suriye

\footnotetext{
* Dr. Öğr. Üyesi, İstanbul Medeniyet Üniversitesi, Edebiyat Fakültesi Tarih Bölümü. e-posta: talhacicek@gmail.com
} 


\title{
Panislamist Propaganda in Syria During World War I: The Case of al-Sharq Periodical
}

\begin{abstract}
This article aims to analyze the discourse of al-Sharq, an Arabic newspaper published in Damascus under Cemal Pasha's patronage during the Great War. The aim of al-Sharq was to propagate Ottoman Pan-Islamism, the official imperial ideology of the Great War, among the Ottoman and non-Ottoman Muslims. By this way, all the world's Muslims would be awakened about the aims of the colonial empires and they would turn to support the Ottoman cause. Prominent Arab intellectuals such as Muhammad Kurd Ali and Shakib Arslan contributed to the periodical as authors and editors. Panislamist themes such as the Caliphate, the importance of the maintenance of the Ottoman Empire, the "treason" of the "rebels" like Sharif Hussein of Mecca and the sultan of Egypt was dwelled on many articles appeared in the columns of the periodical. Besides using the volumes of al-Sharq, the present article draws on the related sources from the Ottoman, British, German and Austrian archives.

In this study, we will examine the life of Mary Mills Patrick and her contributions to Turkish educational system and especially the education of female students in Turkey. We will also focus on her role for the active participation of Turkish girls into educational life within the framework of her booklet mentioned above.
\end{abstract}

Keywords: Cemal Pasha, eş-Şark, Panislamism, Syria 


\section{Giriş}

Osmanlı Devleti'nin I. Dünya Savaşı'na girişi ve buna paralel olarak, Almanya'nın da teşvik ve yönlendirmesiyle, Halife'nin İtilaf devletlerine karşı cihad ilan etmesi, Osmanlı Hilafetini İttifak devletlerinin savaş propagandasının önemli bir unsuru yapmıştı. Cihad ilanı Osmanlı idarecilerini ve Alman hükümetini hem Osmanlı halkları nezdinde, hem de Osmanlı dışı Müslüman toplumlar üzerinde, bütün Müslümanları "küffar"a karşı Halife'nin sancağı altında toplanmaya davet eden Panislamist bir propaganda faaliyetini gerekli kılmıştı. ${ }^{1}$ Bu propagandanın ana teması, Almanya ve Osmanlı Devleti'nin İngiliz ve Fransız sömürgesi altında bulunan Müslüman devletleri, bu boyunduruktan kurtaracağı vaadiydi. Bu çerçevede, Hıristiyan bir devlet olarak Almanya. Osmanlı Devleti'nin müttefiki ve Müslümanların dostu rolünü üstlenmekteydi. ${ }^{2}$

Bu Pan-İslamist söylem, savaş başlangıcında olağanüstü yetkilerle 4. Ordu Kumandanı olarak Suriye'ye gönderilen Bahriye Nazırı Cemal Paşa'nın, Suriye programının da önemli bir parçasını oluşturuyordu. ${ }^{3}$ Zira İslam birliği propagandası yoluyla, hem Suriyelilerin Osmanlı Halifesine bağl1lıkları artacak hem de, o zaman ki Suriye'nin komşusu olan ve İngiliz idaresi altında bulunan Mısır'da, Cemal Paşa'nın organize edeceği bir saldırı harekâtı ve Mısırlıların silahlı desteğiyle Osmanlı hâkimiyeti yeniden tesis edilecekti. ${ }^{4}$ Mısır'ın fethi için yapılacak bir askeri harekât ve bu harekâttan cesaret alacağı düşünülen Mısırlıların isyan

1 Cihad ilanının Alman projesi olduğunu iddia eden bir çalışma için bkz.: Tilman Lüdke, Jihad made in Germany: Ottoman and German propaganda and intelligence operations in the First World War, Münster: LIT Verlag, 2005; 'Alman yapımı' cihad yaklaşımlarını reddedip, Osmanlı Devleti'nin politikaları için Cihad propagandasının merkezi bir yer işgal ettiğini savunan çalışmalar için bkz.: Mustafa Aksakal. "'Holy War Made in Germany’? Ottoman Origins of the 1914 Jihad." War in History 18/2 (2011): 184-99; M. Talha Çiçek, "Visions of Islamic Unity", Die Welt des Islams 54 (2014): 460-482; savaş dönemi Osmanlı propaganda broşürleri üzerine bir çalışma ve bu broşürlerin Almanca, Arapça ve Türkçe metinleri için bkz.: Gottfried Hagen, Die Türkei im Ersten Weltkrieg, Frankfurt am Main: Peter Lang, 1990.

2 Mustafa Aksakal, Harb-i Umumi Eşiğinde: Osmanlı Devleti Son Savaşa Nasıl Girdi, İstanbul: Bilgi Üniversitesi Yayınları, 2010, s. 19-20.

3 Cemal Paşa'nın Suriye'deki faaliyetleri üzerine yapılmış bir çalışma için bkz.: M. Talha Çiçek, War and State Formation in Syria: Cemal Pasha's governorate during World War I, (London: Routledge, 2014).

4 Mısır Harekatı üzerine yapılmış bir çalışma için bkz: M. Talha Çiçek, "The Holy War in Syria: Cemal Pasha and the Ottoman plan to conquer Egypt in the First World War" War \& Society 35/1 (2016): 39-53. 
ederek Osmanlı birliklerine katılması, savaş boyunca Cemal Paşa’nın Suriye’deki en önemli siyasi/askeri hedeflerinden biri olmuştur. ${ }^{5}$

Cemal Paşa'nın yürüttüğü Panislamist propagandanın bir diğer ayağı da Suriye halkının Osmanlı Halifesine olan sadakatlerinin artırılması ve Suriyelilerin bu yönde bir siyasi bilince sahip olmalarının sağlanmasıydı. ${ }^{6} \mathrm{Bu}$ makale boyunca incelenecek Eş-Şark Gazetesinin kurulması da, Cemal Paşa'nın Suriye' de bu yöndeki en önemli faaliyetlerinden birisiydi. Bu makalede, Cemal Paşa'nın öncülüğünde Arapça olarak yayınlanan ve Suriye içinde ve dışında yaşayan Araplara Osmanlı Halifesi etrafında İslam birliği propagandası yapmayı hedefleyen eş-Şark gazetesinde ele alınan belli başlı konular incelenerek Osmanlı Devleti'nin İttiad-ı İslam temalı Savaş propagandası anlaşılmaya çalışılacaktır. Makalede, Gazetenin the British Library'deki nüshalarından istifade edilmiştir.

\section{Gazetenin Kuruluş Süreci ve Amaçları}

Suriye'de Panislamizm propagandası yapacak bir gazete fikri Alman oryantalist Baron von Oppenheim'e aitti. Oppenheim, başlangıçta gazeteyi Alman destekli olarak Osmanlı Devleti’nden bağımsız çıkarmayı düşünmüştü. Fakat müttefikler de dâhil olmak üzere, Suriye'de her türlü yabancı nüfuzuna karşı olan Cemal Paşa, Osmanlı ve Alman propagandası yapacak bir gazetenin çıkarılması fikrini desteklemekle birlikte, bunun tamamen kendi kontrolü altında olmasını istiyordu. ${ }^{7}$ Aşağıda da görüleceği gibi gazetedeki Alman propagandası neredeyse Osmanlı-Alman ittifakının meşrulaştırılmasıyla sınırlı tutulmuştu. Ayrıca, o tarihlerde Cemal Paşa'nın yakın çevresinde yer alan Arap

5 I. Dünya Savaşı döneminde Mısır’a yönelik Osmanlı ve Alman faaliyetlerine dair çalışmalar için bkz.: Donald McKale, War by Revolution, Kent: The Kent University Press, 1998; Salvador Oberhaus, “Zum wilden Aufstande entflammen”: Die deutsche Propagandastrategie für den Orient im Ersten Weltkrieg am Beispiel Ägypten, Saarbrücken: VDM Verlag, 2007. 6 Suriye'ye geldikten hemen sonra, Cemal Paşa, Osmanlı hilafetinin propagandasını yapacak Selahaddin-i Eyyubi Külliyesi adında bir üniversite kuracaktı. Bu külliye hakkında yapılmış detaylı bir çalışma için Martin Strohmeier, Al-Kulliya as-Salahiya in Jerusalem: Arabismus, Osmanismus und Panislamismus im Ersten Weltkrieg, Stutgard: Kommissionsverlag Franz Steiner, 1991; bu külliye hakkında yapılmış Türkçe bir çalışma için bkz.: Kenan Ziya Taş, Kudüs Selahaddin-i Eyyubi Külliye-i İslamiyesi, (İstanbul: Post Yayınları, 2016).

7 Almanlar tarafından Medine'de Alman yanlısı bir Gazete çıkarma girişimi de benzer gerekçelerle engellenmişti. Gazete'yi kurmakla görevlendirilen Said Mehmed Me'mun'un bahsi geçen gazeteye izin almak için giriştiği bütün teşebbüsler sonuçsuz kalmıştı. Alman diplomat Metternich'in ifade ettiğine göre, bu engellemelerden dolayı Me'mun en sonunda bu teşebbüse Osmanlı hükümeti nezdinde önderlik etmekten feragat etmişti. Alman Büyükelçiliği'nin bu gazetenin çıkması lehinde bir teşebbüste bulunması da faydadan ziyade zarar getirmişti. Metternich'in ifade ettiğine göre, Me'mun Osmanlı otoriteleri nezdinde temel olarak bir alman ajanı olarak görülüyordu: PA-AA, Türkei 165, Bd.39, Metternich'den Bethmann Hollweg'e, İstanbul, 20 Ağustos 1916. 
gazeteci Muhammed Kürd Ali'nin hatıratında geçtiği üzere, I. Dünya savaşı dönemlerindeki Osmanlı Suriye'sinin mutlak hâkimi, Oppenheim'i “hilekar" bir adam olarak görmekteydi. ${ }^{8}$

Cemal'den başka, Suriye'deki diğer Osmanlı idarecileri de Oppenheim' in Şam'da Alman yanlısı bir gazete çıkarma girişiminden rahatsızlardı. Suriye Valisi Hulusi Bey, 15 Eylül 1915’te, Oppenheim'in çıkarmayı planladığı gazetenin yol açabileceği problemleri Talat Paşa'ya aşağıdaki cümlelerle özetliyordu:

"Suriye havalisinde Alman nüfuzunun tamimi için müracaat edilen vesaitten en mühimi Şam'da bir gazete neşri olduğunu 28/29 Temmuz 1331 tarihli tahrirat ile ber-tafsil arz etmiş idim. Bu gazete işini akim bırakmak için yazdığım talimat ahkâmı Cemal Paşa tarafından şayan-1 kabul görülmediğinden Şam'da bulunduğu müddet zarfındaki tetkikatım neticesi propagandaya memur olduğuna katiyen şüphem kalmayan Baron Ophenheim'in programını temin edecek ol vechle bir talimat tanzim ve bade'l-mütalaa müeddası telgrafla tasdik olunmak üzere posta ile Enver Paşa hazretlerine takdim olunduğunu haber aldım. Güya bu gazete İslamların hilafet makamı etrafında ittihadını ve devlet-i aliyenin tealisini temine hadim olmak üzere Arab lisanıyla el-İslam namıyla Şam'da neşr edilecekmiş. Eğer maksat bu ise hilafet merkezi İstanbul'dur. Devletin resmi lisanı Türkçe'dir. O halde mezkûr gazete Türkçe olarak İstanbul'da neşr edilsin. Makalat-1 mühimmesini gerek bu havalide gerek münteşir gazetelere derc ettirilmek ve gerekse icab eden mahallere gönderilmek üzere Arapçaya tercüme ve tab ettirilsin. Yoksa daha meydanda gazete falan yok iken uleması arasında mücerred Almanlar'dan beş on guruş alabilmek emeliyle gayr-i Müslim bir devletin İslamları izmihlalden kurtaracağına dair hadis-i nebevi icad ve anın da Alman hükümeti olduğunun şimdi anlaşıldığını iddia etmeye cüret-yab olacak kadar haris bir muhitte Arabiyü'l-ibare böyle bir gazetenin neşrine müsaade etmek kendi elimizle bu havalide Alman nüfuzunun tamimine ve kendi nüfuzumuzun kesrine muvafakat eyleyecektir. Velhasıl mezkur gazetenin burada neşir idame-i emniyet ve siyasete mahzurları olacağı müstelzim olduğundan büsbütün neşrinden sarf-1 nazar ettiril-

8 Kürd Ali, hatıratında Cemal Paşa'nın Oppenheim hakkında kendisine şunları söylediğini ifade etmektedir: “...Paşa bana dedi ki: 'Baron [Max Freiherr von] Oppenheim'i tanıor musun? Ona 'Kendisini Mısır'dan iyi tanırım' dedim. Bana 'Ondan sakın! Hilekâr bir adamdır!' dedi. Cemal Paşa'nın bu tavsiyesini aklımda tuttum ve gereğince hareket ettim”: Muhammed Kürd Ali, Bir Osmanll-Arap Gazetecinin Anılarl, İstanbul: Klasik Yayınları, 2006, s. 176. 
mesi veyahut ber-vech-i maruz İstanbul'da neşr olunması esbabının istikmaline çalışılmasına ve bu babdaki emr-i cevaplarına intizar eylerim." "9

Aynı şekilde, ATASE Arşivindeki bir belgeden anlaşıldığına göre Enver Paşa da Oppenheim'den şüpheleniyordu. ${ }^{10}$ Bütün bu çekincelerin bir sonucu olarak gazetenin Cemal Paşa'nın kontrol ve denetimi altında Osmanlı hükümeti tarafından yayınlanmasına karar verildi. Başlangıçta gazetenin ismi Oppenheim'in önerdiği şekilde el-İslam olarak düşünüldü. Hatta gazetenin programı bile el-İslam olarak hazırlanmıştı. Daha sonra gazetenin adının el$B a$ 'as [diriliş] olarak önerildi. ${ }^{11}$ Fakat son anda gazetenin adının eş-Şark olmasina karar verildi.

ATASE Arşivi'nde mevcut olan programında Gazetenin yayınlanma amacına dair şu bilgiler verilmekteydi:

“Gazetenin asıl maksadı, İslâmlar arasında ittihad-ı mukarrarat teminine çalışmaktır. Bu maksadın temini için Hükûmet-i Osmaniye haricinde yaşayan Müslümanlara anasır-1 kavmiye ve hürriyet-i kadimelerini ihtar ederek, onlarda bir vicdan-1 millî uyandırmaya ve istiklal-i idarelerini kazanmaları için meydan-1 cidal ve faaliyete atılmalarını teşvike çalışılacaktır.

Düşmanlarımız bilhassa Suriye'de telkinat-1 fesadcuyane icra ve birtakım bedhâhları bu alçakça tezvirata alet etmeye çalışıyorlardı. Gazete bütün kuvvetiyle bunların mahiyetini teşrii ve su-i tefhimatı izale edecektir.

Harb-1 hazırda ve her ihtiyaç görüldüğü vakit bütün İslâmları cihad-1 mukaddes için hazırlayacak ve kendilerini halife-i izamımızın irade buyurdukları surette müştereken ifayı vazifeye davet edecektir.

Misır'1n İngilizler elinden kurtularak tekrar muhtariyetini kazanması ve vatanı aslînin yine bir cüzü olması için bütün kuvvetiyle çalışacaktır.

9 BOA, DH.ŞFR. 489/27, Hulusi'den Talat'a, Şam, 2 Eylül 1331 [15 Eylül 1915]; Hulusi aynı telgrafı bir gün sonra Başkumandanlık Vekâletine de gönderecekti: ATASE Arşivi, Kls. 531, Ds. 843-2078, Hulusi'den Başkumandanlığa, 3 Eylül 1331 [16 Eylül 1915]; Hulusi Bey'in projeye yönelik eleştirel tavrı Cemal Paşa'yla yaşadığı iktidar mücadelesinden kaynaklanmaktaydı. Cemal Paşa ile Hulusi Bey arasında Suriye'de benimsenecek idari yaklaşımlar konusunda ortaya çıkan anlaşmazlıklar hakkında bkz.: M. Talha Çiçek, "Myth of the Unionist Triumvirate: The formation of the CUP factions and their impact in Syria during the Great War", Syria in World War I: Politics, Economy and Society, Editör: M. Talha Çiçek, (London: Routledge, 2016), 9-36.

10 ATASE Arşivi, Kls. 272, Ds. 1120, Tarihsiz.

11 ATASE Arşivi, Kls. 531, Ds. 843-2078, Tarihsiz. 
Gazete sadece siyasetle iştigal etmeyecektir. Aynı zamanda Suriye kıt'asının terbiye-i maddiye ve maneviyesi için sahifelerinin büyük bir kısmını ilmî, iktisadî ve ahlaki mübahase hars edecektir. Ezcümle Suriye ahalisi ve gençliği nezdinde vatanperverliğin ikaz ve takviyesine çabalayacaktır. Halkla İslâmların büyük medenî mazisine ait tafsilat vererek onları kendi hususî hazlarını ve kendi zayi nefislerini unutmamaya davet edecektir. Maarif-i umumî namına ahalice veya Hükûmetçe yapılması icap eden işler hakkında daima münakaşat ve müdafaatta bulunacaktır. Şimdiye kadar herkes saadet-i şahsiyesini memleketin haricinde arıyor. Ve servet-i memleketten ecnebiler istifade ediyordu. El-İslâm memleketimizin servetinden artık kendi ahalimizin istifade ve temin-i servet etmeleri fikrini tamime çalışacaktır. Bunun için muhacerat aleyhinde bütün mevcudiyetiyle mücadele edecektir."12

Programında bahsedilen amaçlarından da anlaşılacağı gibi Gazete'nin Suriye için amacı, Suriyelilerin Osmanlı Hilafetine bağlılıklarını artırıp Arapçıların ve Büyük Güçlerin etkilerini azaltmaktı. Avusturya Şam Konsolosu'nun ifadesiyle:

“Ülke içine yönelik olarak bu gazetenin amacı Jön Türklerin devlet fikirlerinin Arapça olarak savunulmasıdır. Bu gazetenin kuruluşu açıkça Suriye'nin yabancı etkisinden kurtarılması amacına matuftur ve bu şekilde politik ilişkilerin dönüştürülmesi hedeflenmektedir. Halkın devlete sadakatinin sağlanması için böyle bir organın oluşturulması gerekli idi. Çünkü, Şam'da çıkan neredeyse bütün gazeteler adem-i merkeziyetçilerin zamanından kalmadır ve az ya da çok Arabist reform hareketinin etkisi altındadır. Her ne kadar onların tutumları o zamandan beri çok değişmiş olsa da propaganda aktivitesinde eski fikirlerinden etkilenmiş olabileceklerinden dolayı onlara çok güvenilemez. Bu gazetenin kurulmasını hükümet Araplığa ve Arap diline dair iyi niyetinin bir göstergesi olarak [sunmayı] da planlamaktadır."13

Ayrıca, Osmanlı hâkimiyeti altında bulunmayan Müslümanların da milli bir bilinç kazanarak, sömürgesi altında bulundukları devletlerden bağımsızlıklarını elde etmeleri için çalışacaktı. Yine Avusturya Şam Konsolosu Ranzi’nin anlatımıyla:

"Sadece Arapça dilinde yayın yapacak olan gazete Pan-İslamist eğilimiyle karakterize edilebilir. Çünkü gazeteyi kuranlar bu gazeteyi Arapça dilinin

12 ATASE Arşivi, Kls. 531, Ds. 843-2078, Fih. 2-30, 2-31, 2-32'den akt, Ömer Osman Umar, “Cemal Paşa'nın Suriye'de Arap Milliyetçilerine Karşı Neşrettiği el-İslam Gazetesi ve Programı”, Askeri Tarih Bülteni, 2000/49, s. 133-134.

13 HHStA, PA 38/369, Ranzi'den Burian'a,"Gründung eines neuen arabischen Propagandablattes 'Esch Schark"”, Şam, 1 Mayıs 1916. 
konuşulduğu her yerde dağıtmayı hedefliyorlar. Onlar sadece Türkiye'deki Arapları hedeflemiyorlar aynı zamanda Osmanlı toprakları dışındaki Müslümanları da aynı şekilde etkilemeyi planlıyorlar ve bütün Müslümanların Osmanlı halifesinin önderliğinde birleşmesi için çabalıyorlar." 14

Konsolosun ifadesine göre Gazetenin Pan-İslamist eğilimi sermuharrir Ali Hikmet Nahid Bey’in kişiliğginde belirginleşir. Hikmet Nahit Bey, Londra'daki “Islamic Society”nin eski başkanıydı. Bu kuruluş Mısır ve Hindistan Müslümanlarının çıkarlarını savunmayı amaçlıyordu. Savaşın başlamasından sonra Ali Hikmet Bey İstanbul'a geldi ve Cihan-ı İslam, Sebilurreşad gibi gazetelerde yazılar yazdı. İkinci muharrir ise Havran mebusu, Panislamist Şekib Arslan'dı. ${ }^{15}$

Cemal Paşa'nın ifadesine göre, “bu gazete Suriye ve Filistin'in en münteşir gazetesi" "' olacaktı. Eş-Şark'ın tirajını artırmak için Cemal, Suriye'nin meşhur gazetecisi Kürd Ali'den kendi gazetesi olan el-Muktebes’i bırakıp, yeni açılan gazetede yazmasını istemişti. Kürd Ali gazetenin yazı işleri müdürlügüüü de üstlenmişti. ${ }^{17}$ Gazetenin yazarları arasında Şekib Arslan, Şeyh Abdülkadir el-Mağribi gibi Suriye'nin entelektüel hayatının önemli simaları da bulunmaktaydı. Şekib Arslan'ın ifadesine göre, "gazete büyük bir atılımla yayına başladığında, kaliteli ve kapsamlıydı" ve "Alman müsteşrikler de dâhil olmak üzere herkesin beğenisini kazanmıştı". Fakat çok geçmeden kâğıt sıkıntısı çekilmeye başlanmıştı. Şekib Arslan'a göre, “ikinci sebep de, işe başlarken yönetimin hatırını dikkate almayan bağımsız bir gazete çıkarmaya niyetlen[il]miş olmasıydı”. Bir ay kadar sonra hükümetin gazetenin işlerine el atması, eş-Şark'ın başlangıçtaki değerini ortadan kaldırmıştı. ${ }^{18}$

Gazete, 4 Nisan 1916 tarihinde yayın hayatına başladı. 26 Mart 1916'da çok parlak bir açılış töreniyle gazete yayın hayatına başladı ve ilk sayısı 4 Nisan

\footnotetext{
14 HHStA, PA 38/369, Ranzi'den Burian'a,'Gründung eines neuen arabischen Propagandablattes 'Esch Schark'”, Şam, 1 Mayis 1916.

15 HHStA, PA 38/369, Ranzi'den Burian'a,"Gründung eines neuen arabischen Propagandablattes 'Esch Schark”, Şam, 1 Mayıs 1916; Şekib Arslan başlangıçta gazetenin sermuharriri olarak düşünülmüștü. Fakat onun Dürzi kökenli olduğu gerekçesiyle sermuharrirliği'ne Cemal Paşa itiraz etmiş, bundan dolayı sermuharrirlik Ali Hikmet Nahid Bey'e verilmişti; ATASE Arșivi, Kls. 272, Ds. 1120, Tarihsiz.

16 BOA, DH.ŞFR. 517/17, Cemal'den Talat'a, Şam, 9 Nisan 1332 [22 Nisan 1916].

17 Muhammed Kürd Ali, Anıları, s. 128; daha sonra yazı işleri müdürlüğü İstanbul'dan getirilen Hikmet Nahid Bey tarafindan üstlenilecekti: Arslan, s. 108.

18 Arslan, Anıları, s. 109.
} 
1916 tarihinde yayınlandı. ${ }^{19}$ Açılış törenine Cemal Paşa, Suriye'deki bütün askeri ve sivil otoritelerle birlikte katıldı. Bütün mezheplerin temsilcileri ve şehrin bütün önde gelenleri törende hazır bulundular. Gazetenin açılış duası Şam Müftüsü tarafindan yapild $1 .^{20}$

\section{Eş-Şark'ta Ele Alınan Başlıca Temalar}

Birinci Dünya Savaşı'nda Osmanlı Devleti'nin Arap vatandaşlarına yönelik politikasını anlamlandırmak için hayati önemde olan bu gazetenin bütün sayıları mevcut değildir. İngiltere'deki British Library Eylül 1917 sonrasında basılan sayıların büyük çoğunluğuna sahiptir. ${ }^{21}$ Ayrıca Princeton Üniversitesi'nde de gazetenin yine 1917 'den sonra basılmış bazı nüshaları mevcuttur.

Yukarıda da ifade ettiğimiz gibi, hükümet destekli bir inisiyatif olan $E s ̧-$ Şark'in yazılarından hareketle I. Dünya Savaşı yıllarında Suriye'de takip edilen Osmanlı politikasının temel parametrelerini tespit etmek mümkündür. İttihat ve Terakki Cemiyeti'nin triumvirasından olarak Cemal Paşa, Suriye'ye Osmanlı devlet otoritesini tesis için gönderilmişti ve gazetenin yayınlanmasının en önemli amaçlarından biri daha önce de belirtildiği gibi İttihad-1 İslam fikrinin zeminini oluşturmak ve dolayısıyla Suriyelilerin Osmanlı idaresine olan bağlılıklarını artırmaktı. Bu amaç doğrultusunda gazete, sütunlarının önemli bir kısmını, Suriyelilerin Osmanlı'ya "içten” bir bağlılıkla bağlanmasını engelleyen devlet ve kişilerle mücadeleye ayırmıştı. Bu bağlamda, bu makalelerde bir yandan Suriye'de Osmanlı devlet otoritesinin kuruluşu için tehdit oluşturabilecek Mısır Sultanı Hüseyin ve Hicaz'da Osmanlı'ya isyan eden Mekke Emiri Şerif Hüseyin gibi şahıslar Halife'nin etrafinda oluşmuş olan İslam birliği'ni böldükleri dolayısıyla hedef alınırken, diğer yandan İngiltere, Fransa, Rusya gibi Suriye'de değişik gruplar arasında nüfuzu olan büyük devletlerin Müslümanların birliğine kast etmiş oldukları anlatılıyordu. Önde gelen Arapçıların idam edildikleri haberi de yine ilk defa Eş-Şark’ta duyurulmuştu. Ayrıca Cemal Paşa ve diğer üst düzey Hükümet

19 Cozef İlyas, Tetavvuru 's-Sehafeti 's-Suriye fi Mieti Amm (1865-1965), Beyrut: Darü'n-Nidal, 1976, s. 309. 20 HHStA, PA 38/369, Ranzi'den Burian'a,"Gründung eines neuen arabischen Propagandablattes 'Esch Schark'”, Şam, 1 Mayıs 1916; Şekib Arslan başlangıçta gazetenin sermuharriri olarak düşünülmüştü. Fakat onun Dürzi kökenli olduğu gerekçesiyle sermuharrirliği'ne Cemal Paşa itiraz etmiş, bundan dolayı sermuharrirlik Ali Hikmet Nahid Bey'e verilmişti; ATASE Arşivi, Kls. 272, Ds. 1120, Tarihsiz; Cemal Paşa ile Şekib Arslan'ın iyi ilişkiler içerisinde olmadıkları düşünülürse, bunun Şekib'in Suriye'deki etkisini azaltmaya yönelik bir teşebbüs olduğu da düşünülebilir.

21 Eş-Şark Gazetesi'nin sayılarını www.bl.uk adresinden temin etmek mümkündür. 
yetkilileri duyurularını bu gazeteden yapmaktaydılar. Bu yönüyle, gazete bir nevi hükümet ile halk arasında aracı konumundaydı.

Gazetedeki yazılar daha ayrıntılı olarak incelenecek olursa, Abdülhamid döneminden beri pan-İslamist politikanın en önemli dayanağı olan Osmanlı Devleti'nin, Avrupa'nın emperyalist güçlerine karşı Müslümanları müdafaa ettiği argümanının en çok işlenen tema olduğu görülecektir. Bu bağlamda, emperyalist güçlerin Müslümanlara karşı düşmanlıklarının anlatıldığı bir yazıda, İslam'ın bağımsızlığını sürdürebilmesinin üç ayağı [kutb] olduğu ifade edilmektedir. Birincisi “Kur'an”, ikincisi “Haremeyn eş-Şerifeyn”, üçüncüsü ise "Osmanlı Hilafeti”. İngilizler, Şerifle işbirliği yapmak suretiyle bu üçayağı yok etmeye çalışmaktayd1lar. Müslümanların Avrupa sömürgeciliğinden kurtulabilmelerinin tek yolu olarak da Osmanlı halifesinin etrafında ittifak etmek gösterilmekteydi. ${ }^{22}$

Cemal Paşa'nın sert uygulamaları ve son derece ağır savaş şartlarının etkisiyle Osmanlı idaresine karşı dikkate değer bir tepkinin oluştuğu Suriye'de, Avrupa sömürgeciliği ile Osmanlı yönetimini karşılaştırmak hem halkın Osmanlı Devleti'ne karşı savaşan Avrupa devletlerine karşı sempati duymasını engellemek hem de hükümete olan tepkileri azaltmak için etkili bir metod olarak kullanılmıştır. Bundan dolayı eş-Şark’ta yer alan haberlerde Avrupalıların kontrolünde olan bölgelerde yaşayan Müslümanlara yapılan "zulümlere” değinen yazılar yayınlanmaktaydı. Yazılarda asıl üzerinde durulan konu ise Osmanlı idaresi altında iken savaş öncesinde veya savaş başladıktan sonra taraf değiştiren bazı yerel liderlerin içine düştükleri durumdu. İngiliz ve Ruslarla ittifak yapmış kabile liderleri hakkındaki bir başyazıda, ilk olarak taraf değiştirerek Ruslara iltica eden Abdürrezzak Bey Bedirhâni’nin en sonunda Rusların zulmünden kaçıp Osmanlı başkentine geri döndüğü anlatılmaktadır. Yine aynı yazıda, Basra'da Osmanlı ile birlikte İngilizlere karşı mücadele ederken taraf değiştirip İngilizlerle ittifak yapan Talib Bey en-Nakîb'in “ibretlik” durumu tasvir edilmektedir. Gazetede Talib Bey’in İngilizler tarafından Hindistan'a gönderildiği, fakat kendisinin İngilizlerin Basra'da Müslümanlara yaptıkları zulümlerden haberdar olup yaptığı işten büyük pişmanlık duyarak Hindistan'dan İsviçre'ye oradan da İstanbul'a sığındığı ifade edilmektedir. Ayrıca, Basra'daki halkın tekrar Osmanlı idaresi altında ol- 
mak istedikleri vurgulanmaktadır. Son olarak Şerif Hüseyin'in hareketinin değerlendirildiği yazıda, Şerif'in Mekke'de eskiden olduğu gibi özgürce hareket edemediği ve pek yakında, İngilizlerle yapmış olduğu ittifaktan dolayı Mekke'deki hâkimiyetinin sona erebileceği üzerinde durulmaktaydı. Sonuç cümlesi olarak, Osmanlı hâkimiyetinden çıkan halkların büyük güçlerin “zulümlerini” görüp Osmanlı idaresini yeniden istedikleri ifade edilmekteydi. ${ }^{23}$ Aynı şekilde, Muhammed Kürd Ali tarafından yazılan bir başmakalede, İngiltere'de yayınlanan bir kitaba atıfla İngiliz idaresinin Mısır'daki skandallarından [fezaih] bahsedilmektedir. Makale'de bu ülkede arkeolojik kazılar yapan İngiliz işçilerinin birçok tarihi eseri gizlice ülkelerine kaçırdıkları ifade edilmekte ve İngiliz idaresinin Mısır'da yaptığı yolsuzluk ve zulümler uzun uzun anlatılmaktadır. Kitabın İngiltere’de toplatılmasına karar verildiği de ayrıca belirtilmektedir. ${ }^{24}$

İttifak Devletleri cephesinin savaşın genel gidişatı bakımından avantajlı bir durumda oldukları mesajını okurlara sürekli olarak vermek oldukça önemliydi. Bu bağlamda, Osmanlı Devleti'ne karşı savaşırken Bolşevik Devrimi neticesinde savaştan çekilmek zorunda kalan Rusya'daki gelişmeler de gazete makalelerinde önemli bir yer işgal etmektedir. Rusya'da demokratik cumhuriyet ilan edilmesi münasebetiyle Muhammed Kürd Ali tarafindan yazılan bir başyazıda, bu kararın uygulanmasının zorluğundan bahsediliyordu. Yazara göre Rusya birçok unsurdan oluşuyordu ve bu unsurları bir arada tutmak zordu. Şimdiye kadar istibdad yönetimiyle bir arada tutulmuş olduklarından kısa bir süre sonra bu halklar kendi kendilerini idare etmek isteyeceklerdi. ${ }^{25}$ Bu şekilde, düşman bir devlet olan Rusya'nın kısa sürede dağılacağı mesajı verilmeye çalışılıyordu. Rusya hakkında sık sık haberler yapılarak Osmanlı Devleti ve müttefikleriyle savaşan eski Rus düzeninin yerle bir olduğu ifade ediliyordu. ${ }^{26}$ Yine Rusya hakkındaki bir diğer yazıda Rus dışişleri bakanının yeni Rus hükümetinin barış planları hakkında uzun uzun malumat veriliyordu. Fakat Rusya'da iç karışıklıkların kolay düzelmeyeceği ve Rusya hâkimiyeti altındaki azınlıkların bağımsızlık talep ettikleri ifade

23 Eş-Şark, "Ibretu li’l-Mu’teberîn”, Sayı: 456, 25 Teşrin-i Evvel 1333/25 Ekim 1917.

24 Eş-Şark, "Fezaih fi Mısr”, Sayı: 451, 30 Teşrin-i Evvel 1333/30 Ekim 1917.

25 Eş-Şark, "Cumhuriyyetu Rusiya”, Sayı: 434, 25 Eylül 1333/1917.

26 Eş-Şark, "Mevkifu Krinski”, Sayı: 447, 14 Teşrin-i Evvel 1333/14 Ekim 1917; Eş-Şark, "Rûsiya es-Sâniye”, Sayı: 474, 15 Teşrin-i Sani 1333/15 Kasım 1917; Eş-Şark, "Firâru Krinski”, Sayı: 470, 11 Teşrin-i Sani 1333/15 Kasım 1917; Eş-Şark, "Lenin ve Nûbel”, Sayı: 544, 6 Şubat 1334/1918; Eş-Şark, "el-Cumhûriyyâtu'r-Rûsiya", Sayı: 546, 9 Şubat 1334/1918. 
edilmekteydi. Aynı yazıda, İtalya’nın da Rusya'nın durumundan etkilendiği ve silah bırakmayı düşündüğü yazılmaktaydı. ${ }^{27}$ Rusya'nın yeni durumu hakkında bir Rus gazetesinde çıkan ve bu devletin akıbetinin tehlikede olduğunu ifade eden bir yazı tercüme edilerek eş-Şark’ta yayınlanmıştır. ${ }^{28}$ Rusya hakkında sık sık haberler yapmak suretiyle Osmanlı ve müttefiklerinin savaşta "avantajlı" olduğu izlenimi verilmeye ve böylece Suriyelilerin devlete olan güveninin artırılmaya çalışıldığı söylenebilir.

Bir propaganda gazetesi olarak kurulan eş-Şark'a atfedilen en önemli görevlerden biri de Hıristiyan bir devlet olan Almanya ile Müslümanların halifesi arasındaki ittifakı, Pan-İslamist argümanlarla çelişmeden meşrulaştırmaktı. Alman İmparatorunun Savaş esnasında gerçekleşen İstanbul ziyaretinin anlatıldığı bir yazıda, Almanya'nın, düşmanlarıyla savaşında Halife'yle ittifak yaptığını ve Alman İmparatoru'nun hem Osmanlı Müslümanlarının hem de bütün Müslümanların koruyucusu olduğunu ve 400 yıldır Osmanlı'nın dostu olduğu vurgulanmaktadır. Yirmi yıl önceki Suriye ziyaretinde, Kayzer'in 300 milyon Müslüman'ın kardeşi [sadîk] olduğunu ifade ettiği de aynı yazıda not edilmektedir. ${ }^{29}$

Yine aynı bağlamda, gazetede hakkında sık sık yazı yazılan bir diğer konu Osmanlı Devleti ile Almanya arasındaki “derin” tarihsel ilişkilerdi. Gazetede, iki devlet arasındaki ilişkileri tarihsel gelişimini konu alan bir yazı dizisi yayınlanmıştır. İlk olarak, Sultan III. Ahmet döneminde her iki ülke arasında dostça ilişkiler kurulduğu ifade edilmiş, fakat detaya girilmemiştir. Tek örnek olarak Alman imparatorunun Osmanlı sultanından deve satın aldığı vurgulanmıştır. ${ }^{30}$ Dizinin ikinci yazısında 18.yy'da Osmanl1- Alman ticari ve siyasi ilişkileri ve askeri ittifakları, Osmanlı sultanı ve Alman imparatorunun yazışmalarına da referans vermek suretiyle ayrıntılı olarak incelenmiştir. Burada Prusya'nın, Rusya ile olan savaşta Osmanlı'yı desteklediği ifade edilmekte ve Prusya imparatoru Frederick'in Osmanlı sultanı Mustafa'ya gönderdiği ve Osmanlı ordusunun zafer kazanacağına olan inancını belirttiği mektubu alıntılanmaktadır. ${ }^{31}$ Dizinin bir

27 Eş-Şark, “el- Vizaretü’r- Rusiyye ve's- sulh”, Sayı: 448, 16 Teşrin-i Evvel 1333/16 Ekim 1917.

28 Eş-Şark, "Re'yi Rûsî”, Sayı: 463, 3 Teşrin-i Sani 1333/3 Kasım 1917.

29 Eş-Şark, "Dayfu'l-Hılafeti”, Sayı: 450, 18 Teşrin-i Evvel 1333/18 Ekim 1917.

30 Eş-Şark, “Almaniya ve'l- Usmaniyyun: el- Alakat beynehuma munzu'l- kadim-2”, Sayı: 444, 11 Teşrin-i Evvel 1333/11 Ekim 1917.

31 Eş-Şark, “Almaniya ve'l- Usmaniyyun: el- Alakat beynehuma munzu'l- kadim-2”, Sayı: 447, 15 Teşrin-i Evvel 1333/15 
sonraki yazısında ise Osmanlı elçisi olarak Almanya'ya gönderilen Ahmet Resmi Efendi vasıtasıyla III. Mustafa ile Prusya Kralı Frederick arasında gerçekleşen mektuplaşma anlatılmaktadır. Yazıda Prusya kralının Rusya'ya karşı Osmanlı ile ittifak yapmak istediği fakat Sadrazam Ragıb Paşa'nın itirazı yüzünden bu ittifakın yapılamadığı belirtilmektedir. Buna rağmen karşılıklı mektuplarla her iki tarafın birbirlerine dostluk ve sadakat duygularını ifade ettikleri mektup metinleri de yazının içine alınmak suretiyle uzun uzun anlatılmaktadır. Yazıda dikkati çeken bir diğer husus da Prusya kralının ağzından Osmanlı sultanının Mekke, Medine, Kudüs, Biladü'ş-şam, Irak, Mısır gibi Arap topraklarının hâkimi olduğunun ifade edilmesidir. Bunun, Suriye ve Filistin'deki Osmanlı hâkimiyetinin İngiliz operasyonlarılla ciddi bir biçimde tehdit edildiği bir dönemde, siyasi bir mesaj niteliği taşıdığ düşünülebilir. ${ }^{32}$ Almanya ile Osmanlı Devleti arasındaki ilişkilerin incelendiği bir başka yazıda, Alman devletinin I. Dünya Savaşı sırasında Osmanlı Devleti'ne yaptı̆ğ askeri yardımlar anlatılmakta ve bu devletin Avrupa'da Osmanlı'nın tam bağımsızlığını isteyen tek devlet olduğu vurgulanmaktadır. ${ }^{33}$

Gazete Osmanlı-Alman ittifakını meşrulaştırmanın yanında, Alman devletinin askeri olarak ne kadar güçlü olduğunun propagandasını yapmak suretiyle Suriyelileri savaşa motive etmeyi ve Osmanlı ve müttefiklerinin savaşta galip geleceğine olan inancı artırmayı da hedeflemekteydi. Yazılarda, Almanya'nın Harp esnasındaki faaliyetlerine atıf yapılarak Alman ordusunun hem karada hem de denizde ne kadar güçlü olduğu anlatılmaktadır. ${ }^{34}$ Almanya’yı, İstanbul'dan ziyaret eden bir grup gazetecinin yazdıklarına atıf yapılarak Alman harp cephelerinde tam bir nizam olduğu ve cepheler arasındaki iletişimin kolaylıkla sağlanabildıği nakledilmekteydi. Almanya'nın demir ve karayolu bağlantılarının detaylı olarak tasvir edilmesi yoluyla ne kadar güçlü bir savunma kurduğu ifade ediliyordu. Yine aynı yazıda Almanların, Fransızlara karşı olan üstünlüğü dile getiriliyor ve böyle Osmanlı tarafının savaşta avantajlı olduğu mesajı veriliyordu. ${ }^{35}$ Yine bir başka yazıda 1917 yılı sonunda yapılan Almanya'nın İtalya

32 Eş-Şark, “Almaniya ve'l- Usmâniyyûn: el- Alaik beynehuma munzu'l- kadim-3”, Sayı: 452, 21 Teşrin-i Evvel 1333/21 Ekim 1917.

33 Eş-Sark, “ed-Devletu'l-Usmâniyye ve Almaniya”, Sayı: 549, 12 Şubat 1334/1918.

34 Eş-Şark, “A’mâlu'l-Almân el-Harbiyyeti”, Sayı: 464, 4 Teşrin-i Sani 1333/4 Kasım 1917.

35 Eş-Şark, "Sahâfiyyûna ve Almanya”, Sayı: 436, 1 Teşrin-i Evvel 1333/1 Ekim 1917. 
saldırısı bir İtalyan hezimeti olarak haberleştirilmiş ve Alman askeri kuvveti yüceltilmişti ${ }^{36}$ Almanya'nın, Avrupa cephesinde Fransa'ya yaptığı saldırılar da yine Alman askeri başarıları arasında zikredilmekteydi. ${ }^{37}$

Dönemin İttihatç1 yöneticilerinin gözünde, hem Suriye'deki hem de bütün İslam dünyasındaki pan-İslamist politika için en büyük tehdidi kuşkusuz peygamber soyundan gelen birisi olarak Osmanlı Halifesine karşı isyan etmiş olan Şerif Hüseyin oluşturmaktaydı. Mısır'daki Arap milliyetçileri tarafından da desteklenen Şerif Hüseyin, Suriyeli Arapların sadakatini kazanmaya çalışan Osmanlı hükümetinin bu yöndeki politikalarının başarısı için büyük bir meydan okumaydı. Eş-Şark'ta çıkan bir habere göre Şerif, isyan edip İngilizlerle birleştiği günden beri İslam beldeleri ve kutsal Hicaz toprakları için her geçen gün kötülükler sayfasına bir yenisini daha eklemekteydi. Kanal ve Irak Cephesi'nde İngilizlere esir düssen Arap askerlerin Şerif'in komutasında İngilizlerle birlikte Müslümanların temsilcisi olan Halife'ye karşı savaş vermelerinin Müslümanların arasına fitne sokacağı ifade edilerek Osmanlı ordusundan olan ve sayıları her geçen gün artan firarların önü alınmak isteniyordu. "Hüseyin'in, İngiliz, Fransız ve İtalyanlarla Arap beldelerinin parça parça bu devletler arasında paylaştırılması ve Hicaz’da İngiliz hâkimiyetinin kurulması için ittifak etmiş olduğu" bilinmekteydi. Bu ittifakın yakın sonucu da Kabe-i Mukaddese'nin, Şerif'in isyanıyla birlikte İngilizlerin boyunduruğu altına girmiş olmasıydı. Yazıda aynı zamanda, İngilizlerin, Hilafet'in Ehl-i Beyt'e ait olduğu gerekçesiyle Osmanlı Sultanı'nın Halifeliğini kabul etmedikleri ve Kureyş’ten birisi olarak Şerif'i Halife yapmak istedikleri vurgulanmakta ve bu şekilde Müslümanların birliğini bozmayı amaçladıkları da ima edilmekteydi. ${ }^{38}$ Yine Suriye kıtasından Şerif Hüseyin'in hareketine yönelik olası bir desteğin önünü almak için savaşın sonuna doğru ilan edilen genel af, gazete vasitasıyla bütün Suriye'ye duyurulmuştur. Bu isyanın Müslümanların birliğini bozmayı amaçlayan bir İngiliz tezgahı olduğu bu haberde tekrar ifade edilmekte ve pişmanlık duyup Osmanlı Devleti'ne sadakat beyan edenlerin bu oyunu engelleyecekleri mesajı verilmektedir. Bu kişilerinin kendilerinin ve aile-

36 Eş-Şark, "Hezîmetu İtaliya”, Sayı: 461, 31 Teşrin-i Evvel 1333/ 31 Ekim 1917; benzer içerikli bir başka yazı için bkz.: Eş-Şark, "El-Vak'atu'l-Kubra”, Sayı: 467, 8 Teşrin-i Sani 1333/ 8 Kasım 1917

37 Eş-Şark, "el-Iztırâb fî Fransa", Sayı: 472, 13 Teşrin-i Sani 1333/ 13 Kasım 1917.

38 Eş-Şark, "Eş-Şerîf el-Huseyn", Sayı: 431, 22 Eylül 1333/1917. 
lerinin güvende olacakları da gazetede belirtilerek, aksi takdirde Şerif'in safına geçenlerin ailelerinin sürgüne gönderilmesi uygulamasına başvurulacağı üstü örtülü olarak ima edilmektedir. ${ }^{39}$

Pan-İslamist propaganda'nın bir parçası olarak, savaş sonuna doğru Doğu Ürdün'de Osmanlı idaresine karşı Şerif Hüseyin'le birlikte hareket eden Bedevi kabileler de el-Vatanu'l-İslamî'yi bölmeye çalışan “zavallılar” olarak tanımlanmaktadır. Yazıda, kendi "şerli menfaatlerinin” peşinden koşan bu aşiretlerin Osmanlı askerleri tarafından perişan edildikleri ifade edilmekte ve bu “hainlerin”, Allah'a, Rasulüne, Vatan-1 Osmanî’ye, Arap Milliyetçiliğine [elKavmiyyetu'l-Arabiyye] ve İslam Camiasına [el-Câmiatu'l-İslamiyye] ihanet ettikleri tekrar tekrar vurgulanmaktadır. Yine aynı yazıda, büyük aşiret liderlerinin Osmanlı Devleti ile birlikte vatanlarını savundukları ifade edilmekte ve Sina yarımadasında İngilizlere karşı Haremeyn-i Şerifeyn, Harem-i Kudüs, Suriye ve Filistin'i savunurken ölen urbânın (Araplar) cennetle ödüllendirildikleri müjdelenmektedir. Suriye, Filistin, Irak, Yemen ve Arabistan'da Osmanlı ile birlikte savaşan Bedevi kabileler de zikredilerek aslında Arapların büyük çoğunluğunun Osmanlı'ya sadık oldukları mesajı verilmektedir. ${ }^{40}$ Gazete'nin bir başka sayısında da Havranlıların Osmanlı'ya olan sadakatlerinden bahsedilmekte ve dış tahriklere rağmen devlete hizmet etmeye devam etmeleri övülmektedir. ${ }^{41}$

Şerif Hüseyin'le benzer şekilde değerlendirilen bir diğer siyasi lider de Birinci Dünya Savaşı’nın patlak vermesiyle birlikte İngilizler tarafından, Osmanlı taraftarı olan Hidiv II. Abbas Hilmi Paşa'nın yerine tayin edilen ve eş zamanlı olarak bağımsızlığ 1 verilerek Mısır’a Sultan yapılan Hüseyin Kamil Paşa'dır. Gazetenin haberlerinde Hüseyin Kamil "Hidivü’l-Kâzib”, yani sahte Hidiv, olarak nitelendirilmekte idi. Halifenin İslam düşmanları ile savaştığı bu zor dönemde Hidiv, dinin düşmanları ile işbirliği yapmış ve bütün Müslümanlara ihanet etmişti. Hüseyin'in halefi Ahmed Fuad da benzer ithamlara maruz kalmıştı. Fuad, "el-

39 Eş-Şark, Sayı: 478, 22 Teşrin-i Sani 1333/22 Kasım 1917.

40 Eş-Şark, "el-Usatu'l-Hâlikûn”, Sayı: 459, 29 Teşrin-i Evvel 1333/ 29 Ekim 1917; Cemal Paşa'nın, Suriye'de Arap milliyetçilerine savaş açtığı gerçeği düşünüldüğünde, Osmanlı’ya isyan edenlerin Arap milliyetçiliğine ihanet ettikleri söylemi dikkate değerdir. Bu durum, Osmanlı idarecilerinin sadece Türk milliyetçi duygularını değil, çok sık olmasa da, Arap milliyetçi duygularına da başvurdukları şeklinde yorumlanabilir.

41 Eş-Şark, "Hidemâtu'l-Havraniyyînu'l-Meşkûreti fi'l-Harbi'l-Hâzırati ve İkbaliu'l-Hükûmeti's-Seniyyeti aleyhim", Sayı: 460, 30 Teşrin-i Evvel 1333/ 30 Ekim 1917. 
Medresetü'l-Camiati'l-Mısriyye” adında bir üniversite kurmuş ve bu üniversite yoluyla Arapları Osmanlı'ya karşı eğitmeyi amaçlamıştı. Bu şekilde İngilizlerin, Müslümanları bölme hedeflerine hizmet etmiş oluyordu. ${ }^{42}$ Gazete' de İngilizler ve Şerif Hüseyin hakkında çıkan haberlerde de Hidiv’e ve Mısır yönetimine sık sık atıflar yapıldığı görülmektedir.

Gazete'de, emperyalizme karşı İslam birliği politikası çerçevesinde, Emperyalist Avrupa'ya karşı Osmanlı hilafetinin desteğiyle cihad eden Trablusgarblılara dair yazılar da mevcuttur. Trablusgarplıların mücadelesi Suriyeli Arapları hem cihada motive etmek için hem de Suriyelilerin emperyalizme karşı bilenmişliklerini artırmak için başvurulan en önemli tarihsel olaylardandır. Gazete' de yayınlanan yazılardan birinde Trablusgarp'ta Araplar, Osmanlı askerleriyle birlikte İtalya'ya karşı savaştıklarının altı çiziliyordu. Bu eyalet ile diğer Osmanlı toprakları arasında doğrudan kara bağlantısı yoktu ve İtilaf devletleri Trablusgarp’ta savaşan mücahitlere denizden yardım gönderilmesini engellemişlerdi. Bütün bunlara rağmen, bu mücahitler İtalyanlara ağır [cesîme] kayıplar verdirmişlerdi. Daha sonra bu mücahitlerin bir kısmı Tunus sınırında kuşatılmışlar ve Tunus’taki Fransız askerlerinin de yardım ve desteğiyle oradaki direniş hareketi sona ermişti. O günden sonra Trablusgarp'ın bu bölgesinde sükûn vardı. Fakat diğer bölgelerde Trablusgarplı Araplar, İtalyan boyunduruğundan kurtulup bağımsızlıklarını elde edebilmek için var güçleriyle mücadele etmekteydiler. İtilaf devletleri onların mücadelesini engellemek için elinden geleni yaptı. Müslümanların Halifesi cihat ilan ettiği zaman Trablusgarp Arapları, istisnasız olarak bu cihat ilanına katıldılar ve Osmanlı Halifesine bağlılıktan başka kurtuluşlarının olmadığını düşündüler. ${ }^{43}$

Gazete haberlerinin önemli bir bölümü ve manşetlerin dikkate değer bir $r$ kısmı da de savaş yılları Suriye'sinin de facto hâkimi Cemal Paşa hakkındadır. Cemal Paşa'nın yaptığı konuşmalar, yayınladığı beyannameler ve Almanya gibi büyük devletlerin yöneticilerinin mesajlarına verdiği cevaplar Eş-Şark'ın manşetinden yayınlanmaktadır. Bu manşetlerde, Cemal Paşa çoğunlukla devlet başkanları için kullanılan “Sahibü’d-Devleti”, "Sahibü'l-Haşmeti”, "Kâidu'l-âm Suriye ve Bilâdu'l-Arabi'l-Ğarbiyye”, "Munkızu'l-Vatan” [Vatanın Kurtarıcısı] gibi sıfatlarla 
sık sık övülmektedir. ${ }^{44}$ Falkenhayn'ın Suriye'de kurulan Y1ldırım orduları komutanlığına atanmasıyla Cemal Paşa için kurulan ve Suriye'deki yetkilerini önemli ölçüde kısıtlayan "Suriye ve Garbi Arabistan Umum Komutanlığı”na atanması dahi gazetede Cemal'in terfi etmesi olarak haberleştirilmiştir. ${ }^{45}$ Kürd Ali'nin hatıratından öğrendiğimize göre bu haberlerin çoğu Cemal Paşa'nın gazabına uğramak korkusuyla yapılmaktadır. ${ }^{46}$ Cemal Paşa'nın vermek istediği toplumsal mesajlar, konuşma metinlerinin yayınlanması suretiyle gazete aracıllğıyla yapılmaktadır. Özellikle Şerif Hüseyin ve İngilizlerin, Müslümanların, savaşın başlamasıyla birlikte Osman11 halifesi etrafında oluşturdukları birliği bozmaya yönelik hilelerine dair Cemal Paşa'nın yaptığ uzun konuşmalar gazetede yayınlanmıştır. ${ }^{47}$

\section{Sonuç}

Eş-Şark örneği Birinci Dünya Savaşı sırasında Osmanlı Pan-İ́slamist politikalarının Suriye ve Araplar özelinde nasıl belirginleştiğini görmek açısından büyük önemi haizdir. Çok uzun zamandan beri bu ölçekte bir seferberlik ve çatışma alanı olmak tecrübesi yaşamamış olan Suriye ve Filistin topraklarında, halk1 savaşa motive etmek önemli ve ciddi çaba gerektiren bir durumdu. Şerif Hüseyin İsyanının patlak vermesi ve İngilizlerin Filistin'e doğru ilerlemeye başlaması halkın desteğini daha da önemli bir faktör durumuna getirmişti. Osmanlı Devleti'nin İslam'ın son kalesi olarak tasvir edilmesi ve bunun bir ölüm-kalım savaşı olduğunun sık sık vurgulanması, savaş döneminde büyük sıkıntılara maruz kalan halka, bu durumun geçici olduğu mesajı verilerek, demoralizasyonunu engellemeye yönelik bir çaba olarak yorumlanabilir. Sömürge Müslümanlarının durumunun sık sık uzun uzun tasvir edilmesi, yaşadıkları sıkıntılara rağmen Suriye ve Filistin halkının, diğer İslam halklarına kıyasla daha iyi şartlarda olduklarının altının çizilmek istendiği düşünülebilir.

Gazetede yayınlanan yazılardan yola çıkarak, İslamcılık ve Osmanlıcılık

44 Gazetede yayınlanmış bazı Cemal Paşa haberleri için bkz.: Eş-Şark, "Cevabu Sâhibu'l-Haşme Âhidu'l-Almaniya ile Tahiyyeti'd[?]-Devleti Cemal Bâşa”, Sayı: 453, 22 Teşrin-i Evvel 1333/22 Ekim 1917; Eş-Şark, "El-İmbaratûr ve Kâiduna”, Say1: 454, 23 Teşrin-i Evvel 1333/23 Ekim 1917; Eş-Şark, "İhtifâlu'l-Azîm bi teşrîfi Sahibu'd-Devleti Ahmed Cemal Bâşa", Sayı: 461, 31 Teşrin-i Evvel 1333/31 Ekim 1917: Eş-Şark, "Bahriyyetunâ ve Nâzıruhâ", Say1: 457, 27 Teşrin-i Evvel 1333/27 Ekim 1917; Eş-Şark, "Hıtâbu Hazreti Fuad Bey Muâvinu'l-Vâli”, Sayı: 462, 1 Teşrin-i Sani 1333/1 Kasim 1917

45 Eş-Şark, "Terfîu Cemal Bâşa”, Sayı: 496, 25 Teşri-i Evvel 1333/25 Ekim 1917.

46 Muhammed Kürd Ali, Anıları, 142-144.

47 Eş-Şark, "Hitabu Hazreti Sahibu'd-Devleti Cemal Bâşa el-Âlı̂”, Sayı: 494, 9 Kanun-u Evvel 1333/9 December 1917. 
yanında yer yer Arapçılı̆̆ın da Osmanlı idaresi tarafından bir propaganda aracı olarak kullanıldığı söylenebilir. Gazete yazılarında, Osmanlı Devleti'ne karşı isyan edenlerin, zaman zaman "Arap milliyetçiliği"ne de "ihanet" etmekle itham edilmesi, Arap milliyetçilerinin kültürel taleplerinin dönemin Osmanlı elitleri tarafından açıkça hedef alınmadığı şeklinde yorumlanabilir. Bunlar daha ziyade büyük güçlerle işbirliği yaparak Osmanlı Devleti'ne "ihanet" etmekle suçlanmışlardır. Kültürel taleplerine dair açıktan bir karşı çıkma durumu söz konusu değildir. Benzer şekilde, Şerif Hüseyin de kesinlikle Arapların ve Araplığın temsilcisi olarak görülmemiş, bunun yerine bütün Müslümanlara ihanetle suçlanmıştır. Şerif hakkında Eş-Şark’ta sık yayınlanan yazılardan yola çıkarak, Osmanlı yöneticilerinin politik olarak, Şerif'in Suriye'de etkili olma ihtimalinden korktuğu ifade edilebilir. İngilizlerin, Şerif'in isyanını Arap isyanı olarak pazarlama siyasetine karşın, Osmanlılar bu isyanın Arapları temsil etmediğini, hatta Araplara "ihanet" olduğunun altını çizmişlerdir.

Gazete yazılarında da açıkça görüldüğü gibi I. Dünya Savaşı'nda Osmanlı Devleti'nin en önemli propaganda malzemesi "emperyalist" güçlere karş1 Müslümanları koruma propagandası olmuştur. İngiltere, Fransa, Rusya ve İtalya gibi devletler Müslümanları sömürgeleştirmeye çalışan güçler olarak anlatılırken, Osmanlı Devleti çatısı altında olmak ya da onunla işbirliği yapmak bu akıbetten kurtulmanın yegâne yolu olarak ifade edilmiştir. Osmanlı-Alman ittifakı da aynı argümanla meşrulaştırılmış ve Alman imparatoru Osmanlı Sultanını emperyalizme karşı mücadelesinde desteklediği için dost ve müttefik olarak değerlendirilmiştir. Zira gazetedeki yazılarda vurgulanan sürekli olarak Almanya'nın Osmanlı topraklarında gözü olmayan ve onun bağımsızlı̆̆ına saygı duyan tek Avrupa devleti olduğu gerçeğine atıf yapılmasıdır. 


\section{Kaynakça \\ Birincil Kaynaklar}

Eş-Şark Gazetesi, The British Library

Alman Dışişleri Bakanlığı Arşivi (PA-AA)

Türkei 165, Bd.39.

ATASE Arşivi

Klasör 531, Ds. 843-2078

Klasör 272, Ds. 1120.

Başbakanlık Osmanlı Arşivleri

DH.ŞFR. 489/27

DH.ŞFR. 517/17

Avusturya Macaristan İmparatorluğu Dışişleri Bakanlığı Arşivi (HHStA)

\section{Basılı Kaynaklar}

Aksakal Mustafa, “'Holy War Made in Germany'? Ottoman Origins of the 1914 Jihad." War in History 18/2 (2011): 184-99.

, Harb-i Umumi Eşiğinde: Osmanlı Devleti Son Savaşa Nasıl Girdi, İstanbul: Bilgi Üniversitesi Yayınları, 2010.

Çiçek, M. Talha, "Myth of the Unionist Triumvirate: The formation of the CUP factions and their impact in Syria during the Great War", Syria in World War I: Politics, Economy and Society, Editör: M. Talha Çiçek, (London: Routledge, 2016), 9-36.

,"The Holy War in Syria: Cemal Pasha and the Ottoman plan to conquer Egypt in the First World War" War \& Society 35/1 (2016): 39-53.

"Visions of Islamic Unity", Die Welt des Islams 54 (2014): 460-482.

, War and State Formation in Syria: Cemal Pasha's governorate during World War I, (London: Routledge, 2014).

Hagen, Gottfried, Die Türkei im Ersten Weltkrieg, Frankfurt am Main: Peter Lang, 1990.

İlyas, Cozef, Tetavvuru's-Sehafeti's-Suriye fi Mieti Amm (1865-1965), (Beyrut: Darü'nNidal, 1976).

Lüdke, Tilman. Jihad made in Germany: Ottoman and German propaganda and intelligence operations in the First World War, Münster: LIT Verlag, 2005.

McKale, Donald, War by Revolution, Kent: The Kent University Press, 1998.

Muhammed Kürd Ali, Bir Osmanlı-Arap Gazetecinin Anıları, İstanbul: Klasik Yayınları, 2006. 
Oberhaus, Salvador, “Zum wilden Aufstande entflammen”: Die deutsche Propagandastrategie für den Orient im Ersten Weltkrieg am Beispiel Ägypten, Saarbrücken: VDM Verlag, 2007.

Strohmeier, Martin, Al-Kulliya as-Salahiya in Jerusalem: Arabismus, Osmanismus und Panislamismus im Ersten Weltkrieg, Stutgard: Kommissionsverlag Franz Steiner, 1991.

Taş, Kenan Ziya, Kudüs Selahaddin-i Eyyubi Külliye-i Íslamiyesi, (İstanbul: Post Yayınları, 2016).

Umar, Ömer Osman, “Cemal Paşa'nın Suriye'de Arap Milliyetçilerine Karşı Neşrettiği elİslam Gazetesi ve Programı”, Askeri Tarih Bülteni, 2000/49. 